\title{
Methods of Using the Google Classroom Service in Teaching Historical Disciplines During Blended and Distance Learning
}

\author{
Dmytro Nefyodov \\ Doctor of Historical Sciences \\ Associate Professor at the Department of History \\ V. O. Sukhomlynskyi National University of Mykolaiv \\ nefyodovdv@gmail.com
}

\begin{abstract}
The article deals with the methods of using the Google Classroom service in teaching historical disciplines during blended and distance learning. The author of the article has come to the conclusion that with the help of distance education technologies it is not only possible to put a number of routine pedagogical activities on a computer's shoulders, but to organize really qualitative, individual, differentiated teaching. In the author's opinion, in the Google Classroom service it is convenient and effective to work both for a teacher and a student/pupil, as the service provides the users with a generic working device, possesses a human-engineered interface and capabilities necessary for the participants of the educational process.

Key words: higher education institutions, comprehensive secondary institutions, Google Classroom, distance teaching/learning, blended teaching/learning
\end{abstract}

Present-day developments of digital technologies provide the opportunity of their active implementation into the educational process. At present we can highlight a distinct tendency of changing the role of digital technologies - from the common support of the educational process with technical means to formation of electronic educational resources (EER), computer-based learning environment (CBLE) and accomplishment of distance learning.

An advanced training session both in a comprehensive secondary institution (CSI) and in a higher education institution (HEI) can no longer be imagined without using information and communication technologies (ICT), without the combination of traditional teaching means and methods with the ICT tools. The implementation of modern information technologies into the educational process opens new opportunities of solving various pedagogical tasks. With spreading digital technologies teaching/learning takes the form of a continuous, individual-oriented, flexible and dynamic process.

Internet technologies that are quickly mastered by CSI and HEI give the graduating students self-confidence, create comfortable conditions for self-realization and creativity, 
increase their motivation to studies, enlarge their social circle, provide a great amount of various educational resources. And they also open a number of opportunities for a teacher: to highlight a theoretical issue more deeply, that helps the participants of the educational process to scrutinize thoroughly processes and phenomena, which could not be studied without using the interactive models; they are also the infinite possibilities for realization of inclusive education etc.

The present and the future of our pupils and students is a knowledgeable society. The academician Andrei Petrovich Semenov's statement "To teach a person to live in the information world is the most important task of the contemporary school" must become determinative in the work of every modern teacher.

In the light of these processes the distance teaching systems are to the fore today. These systems have long been known to the teachers of HEI. But CSI discovered the distance teaching relatively recently due to the quarantine with regard to the coronavirus pandemic and had to cope with it as fast as possible.

Let's give deeper consideration to the Google Classroom system, which has become widespread due to its simplicity and accessibility for the participants of the training process. For the last part of May 2014 the Google company began its limited testing of its educational platform "Classroom", intended for classroom studies. According to the Google information, for the first few months more than 100 thousand people from 45 countries enrolled to try this service. Today any person who has a Google account can start using it. This system of training can be used both on a computer and on a slate or a smartphone.

Access to this software is possible after a user's registration and receiving a normal user Google account.

With Google Classroom a user can make a training classroom or join the existing one. A number of training groups that a teacher can make and a pupil can be enrolled is unlimited.

While scheming an online-classroom a teacher (instructor) adheres to the following principles:

- of scientificity and feasible difficulties;

- of availability of education;

- of visibility;

- of awareness and creative activity; 
- of enriching and educative nature of teaching;

- of creating a positive emotional background.

In the Classroom you can use (download) textbooks, lectures, presentations on topics as well as videos from YouTube.

In Google Classroom teachers can easily and quickly make and check tasks in the electronic form, and also determine a delivery date. The tasks and pieces of work are then automatically systematized into the structure of folders and documents on Google Drive, understandable both to teachers and students. With the help of the service you can immediately see the tasks, which caused some problems while doing them.

The peculiarities of the Google Classroom system are as follows:

- the usage of only Google tools (Google Drive, Google Documents, Google Forms etc.);

- a common folder "Classroom" is made on Google Drive for the participants of the educational process;

- the folder "Classroom" is available both for the individual student and for the class (group) in general.

The advantages of the Google Classroom system are as follows:

- the functionality: the ability to publish the theoretical material, tasks, to post grades in the register, a calendar etc;

- the organization of collective work;

- the free-of-charge basis;

- the support of the Ukrainian language;

- the brand Google is known and used by everyone;

- this service can be used both on a personal computer and on a smartphone and a slate, as well as with the help of special mobile applications.

The Mykolaiv economic lyceum № 2 of the Mykolaiv city council activated the complimentary subscription to the G Suite for Education service since the first weeks of distance teaching/learning in March 2020.

Doctor of Historical Sciences, Associate Professor of the Department of History of Mykolaiv V.O. Sukhomlynskyi national university D.V. Nefyodov combines his work at the university and teaching disciplines of a social humanitarian cycle in the Mykolaiv economic 
lyceum № 2. Since the first days of moving to the distance teaching/learning he began to use the Google Classroom service in his work together with his colleagues.

Thus, each subject which is taught (History of Ukraine, World History, Foundations of Legal Studies, Civics) and each class (group) of the lyceum has the appropriate Classroom on the Google Classroom service.

In the Classroom all classes and lessons are arranged according to the usual timetable, the tasks and explanations for doing them are made and downloaded, the deadlines are set. Having done his homework each student sends it to the Classroom and after checking it by the teacher he gets a sufficient grade (fig. 1).

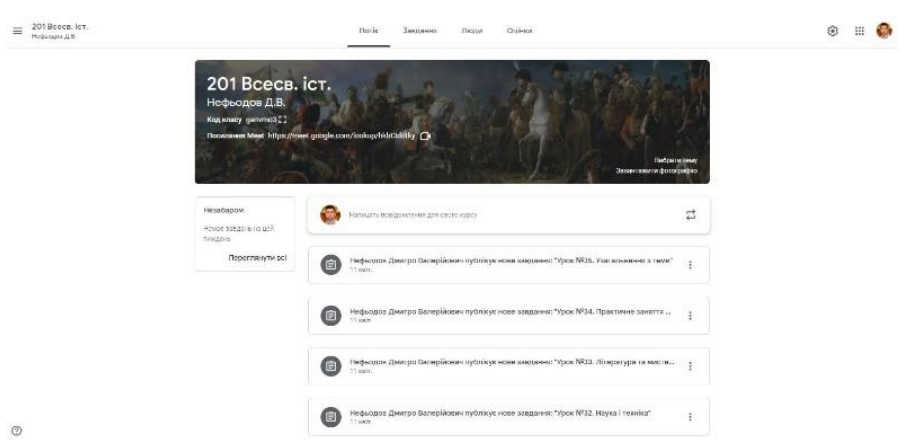

Fig. 1.

Besides that, the service has tools for arranging all the students' grades in the format of a register and striking an average grade for a topic, a semester, a year.

One of the most important tools of the Classroom is also the service "meet" - the opportunity to give classes in the format of a video-conference (fig. 2).

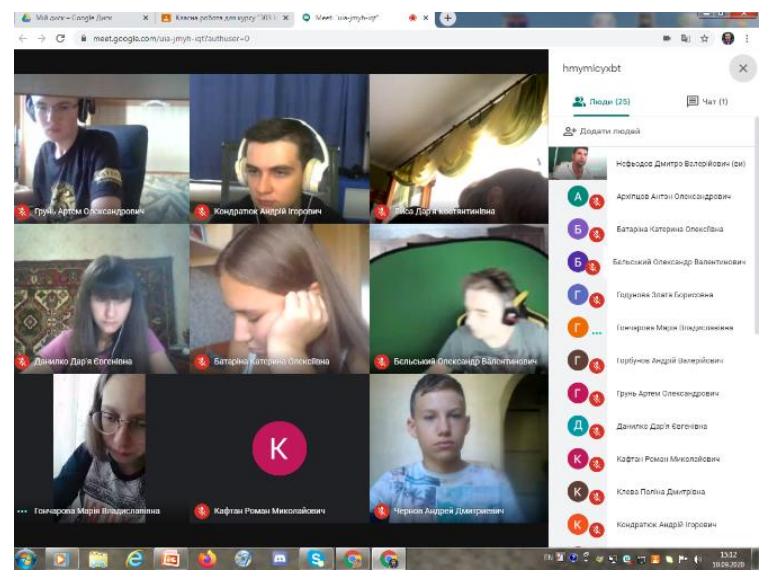

Fig. 2 
Thus, we can make a conclusion that with the help of distance education technologies it is not only possible to put a number of routine pedagogical activities on a computer's shoulders, but to organize really qualitative, individual, differentiated teaching.

The Google Classroom service allows to avoid the organization problems of providing consumer's choice service, such as an e-mail, calendar and Drive service, and to focus on those things which a teaching establishment and a teacher must be engaged - in expanding the resources for more qualitative support of the educational process.

Google Classroom possesses a lot of opportunities: making tasks which are integrated with Google Drive; electronic collaboration on tasks, that provides a two-way communication between a student and a teacher; communication in online mode; assessment of the tasks which have been done.

In our opinion, in the Classroom it is convenient and effective to work both for a teacher and a student/pupil, as the service provides the users with a generic working device, possesses a human-engineered interface and capabilities necessary for the participants of the educational process.

\section{References}

1. Gazeykina A.I., Toporova N.V., Udartseva D.A. Primenenie servisa Google Classroom dlya organizatsii domashney rabotyi $v$ shkole [The usage of the Google Classroom service for organization of homework at school] // Aktualnyie voprosyi prepodavaniya matematiki, informatiki i informatsionnyih tehnologiy. 2019. № 4. S. 214220.

2. Demeshkevych V. Osoblyvosti vykorystannia servisiv Google $v$ diialnosti pedahohichnykh pratsivnykiv [The peculiarities of using Google services in teaching employees' activity] // Oblasna naukovo-praktychna Internet-konferentsiia «Shliakhy efektyvnoho vprovadzhennia osvitnikh tekhnolohii u navchalnykh zakladakh». Kirovohrad, 2016. Rezhym dostupu: http://konf.koippo.kr.ua/blogs/index.php/blog12/title-434.

3. Plish I.V. Vykorystannia informatsiino-komunikatsiinykh tekhnolohii upravlinnia yakistiu osvity $v$ shkolakh pryvatnoi formy vlasnosti [The usage of information and communication technologies of education quality management in privately operated schools] // Informatsiini tekhnolohii i zasoby navchannia. 2012. № 1 (27). Rezhym dostupu: http://journal.iitta.gov.ua

4. Tulina E. Kratkiy obzor osobennostey i funktsiy LMS-sistemyi ot tsifrovogo giganta Google [A brief review of peculiarities and functions of the LMS system from the digital giant Google] // Vvedenie v Google Classroom. 2014. Rezhim dostupa: https://newtonew.com/news/vvedenie-v-google-classroom 
5. Chumak L.O. Mozhlyvosti servisu Google Classroom dlia orhanizatsii navchalnoho protsesu [The Google Classroom service facilities for organization of the educational process] // Visnyk Prydniprovskoi derzhavnoi akademii budivnytstva ta arkhitektury. 2018. № 6. S. 65-70. 